\title{
From contaminated site to premier urban greenspace: investigating the success of Thames Barrier Park, London
}

\author{
J. Villella, G. Sellers, A. J. Moffat \& T. R. Hutchings \\ Environmental and Human Sciences Division, Forest Research, UK
}

\begin{abstract}
Thames Barrier Park, opened in 2000, is situated on the River Thames adjacent to the Thames flood barrier in the ethnically diverse and economically deprived London borough of Newham (LBN). At nine hectares, it was one of Britain's most expensive areas of greenspace development costing $£ 12 \mathrm{~m}$ to construct on a formerly contaminated wharf. With annual running costs of $£ 700 \mathrm{k}$, it far exceeds the budgets available for the maintenance of similar greenspaces in the area. It was designed by French landscape designers using Parc Citroen in Paris for inspiration. The park's original aims were: to be an area of multifunctional greenspace amongst new apartment and commercial developments, to improve surrounding house and land prices and promote the area as a pleasant place to live and work, to become a tourist destination and be seen as an integral part of a wider scheme that would draw tourists into the area. The aim of this paper is to assess whether the park was meeting or would meet its objectives. An independent survey of the local community and park users, utilising postal surveys, user questionnaires and focus groups was undertaken. Results suggested that the park had been as successful in attracting local and non-local users. Users of the park did not reflect the make up of the local population, tending to attract slightly wealthier members of the community who were predominantly white, in an area of high ethnicity and low income. This paper identifies future developments that will possibly transform this park's prospects of meeting its original aims and offers proposals on ways to achieve its wider objectives whilst meeting the needs of the local community and highlights important considerations for future urban greenspace design.
\end{abstract}

Keywords: contamination, brownfield regeneration greenspace urban park, tourism ethnicity, community. 


\section{Introduction}

Thames Barrier Park, fig 1, is constructed on a former dock and factory site that handled and processed industrial chemicals. After closure of the older docks in the $1960 \mathrm{~s}$, these contaminated sites became derelict. However, with the creation of the London Docklands Development Corporation (LDDC) in 1981 these areas began to be regenerated, mainly for housing and commercial development. A number of sites, of which Thames Barrier Park is just one, were converted to premier greenspace use.

Thames Barrier Park aimed to achieve a number of objectives. It was to be an area of multifunctional greenspace for the local population amongst new apartments and commercial developments. It was to improve surrounding land and house prices so that the area would be seen as an pleasant place to live, work and invest in, and it was to be an integral part of a projected wider tourist development plan, to include an aquarium development opposite the park, that would draw tourists into London Docklands, Riley [1].

The park is situated in the London Borough of Newham (LBN) adjacent to the River Thames in east London. Newham is an ethnically diverse borough due to its proximity to the old docklands and has a number of migrant communities LBN [2].

The creation of the park took place in two phases. The first phase began in 1997, and involved clearing the derelict land of physical structures and the removal of visibly contaminated soils together with a $300 \mathrm{~mm}$ layer of crushed concrete that had been added previously as a capping material. A 'cut and fill' operation created the final formation profile and a capillary break layer was added to seal off the subsoil beneath. Constructed areas such as a 'Green Dock' and fountain area were also created Riley [1]. Phase Two began in 1998 and involved the primary landscaping works. A mainly clayey topsoil was placed over the capillary break layer to a depth of between $1 \mathrm{~m}$ for the wildflower meadow and grass areas to $2.5 \mathrm{~m}$ for areas planted with trees. As part of the wider regeneration remit for the Newham and Docklands area, a Docklands Light Railway (DLR) station was constructed in December 2005 at the main park entrance, which should improve access to the park and bring in visitors from other areas of London. It is envisaged that this will help the park compete not only with other suburban parks at Greenwich and Battersea, but also the major city centre parks such as Green Park and St James' Park. Furthermore, the 2012 Olympics, awarded to London, will be predominantly based in Newham and Docklands, which should improve the visitor prospects for the park.

The park is 8.9 hectares in size and cost $£ 12$ million to construct. An annual budget of $£ 700000$ per annum is used for park management, landscape maintenance, and marketing Lewis [3]. The objectives of this study were to investigate whether the park had, or was on the way to meeting, its stated objectives and suggest practical solutions to improve the functional usage of the park in the future. 


\section{Methodology}

\subsection{Community postal questionnaire}

Five hundred community questionnaires were sent out to residents in the London Borough of Newham. The questionnaire covered subjects such as people's opinions of parks and what they considered an ideal park, whether they visited parks, in particular Thames Barrier Park, and what mode of transport they used to travel there. It included subjects such as age, ethnicity and income.

\subsubsection{Thames Barrier Park on-site visitor survey}

Two sets of information were collected. A count of the number of visitors entering the park was made and a visitor survey was conducted. The on-site survey took place over three days on Saturday $30^{\text {th }}$ June $(8.30-18.30)$, Sunday $31^{\text {st }}$ June $(8.30-18.30)$ and Tuesday $2^{\text {nd }}$ August $(8.30-18.30) 2005$. It was in the form of a questionnaire where people either filled in the form directly or were asked the questions verbally and the sheet filled in by the canvasser. A total of 103 surveys were completed, the majority in the first two days. Towards the end, the people visiting the park tended to be repeat visitors who had been surveyed in the first two days. The survey sought to determine who used the park in terms of gender, age, income and ethnicity, how they used the park, how they travelled to the park, what they liked about the park and how the park could be improved.

\subsection{Focus groups}

Eight members of the local community were invited to attend a focus group session on the $19^{\text {th }}$ July 2005 . There were three women and five men from a variety of socio-economic backgrounds but they all came from a white ethnic background. The aim of the focus group was to allow the participants to explore further their feelings about the park that had been collectively raised in the questionnaire survey.

\section{Results}

\subsection{Community questionnaire}

Of the 500 questionnaires sent out, only 34 were returned (6.8\%) which is a poor response and inevitably limits the strength of the conclusions that can be drawn about the greenspace values that are held by the inhabitants of Newham. Nevertheless, the results indicate that there are probably differences in attitude between those who use the park and those who are neighbours to it, which require study and a more narrowly focused sampling strategy.

Of the 34 park neighbour responses, only five had never visited the park and only two of the respondents were men. The reasons for not visiting the park were that they had never heard of it, they did not have enough time to visit, they could not access the park because of a disability or had not because of fear of intimidation. 
As shown in table 1,the majority of respondents were either: people in their 30 s or those aged $60+$. The other age categories were not nearly as likely to use the park.

When it came to a question of income $44 \%$ did not answer the question. The census figures on Newham, LBN [2], say that the average household income is $£ 27000$. Table 1 suggests that the community survey data does reflect the census data. However, as table 1 shows, he community survey did not reflect the census results for ethnicity, which identifies Newham as a multi racial community with a white population of $40 \%$. In contrast, the community survey suggests that respondents were overwhelmingly of white ethnicity.

Table 1: Summary of age, income and ethnicity data obtained from the community survey.

\begin{tabular}{|c|c|c|c|c|c|c|}
\hline Age & $20-29$ & $30-39$ & $40-49$ & $50-59$ & $60+$ & \\
\hline $\begin{array}{c}\text { Percentage } \\
\text { who replied }\end{array}$ & 11.8 & 29.4 & 5.9 & 2.9 & 35.3 & \\
\hline $\begin{array}{c}\text { Gross } \\
\text { Household } \\
\text { Income }\end{array}$ & $\begin{array}{c}£ 0- \\
9999\end{array}$ & $\begin{array}{c}£ 10000 \\
-19999\end{array}$ & $\begin{array}{c}£ 20000 \\
-29000\end{array}$ & $\begin{array}{c}£ 30000 \\
-39999\end{array}$ & $\begin{array}{c}£ 40000 \\
-49999\end{array}$ & $\begin{array}{c}£ 50000 \\
-99999\end{array}$ \\
\hline $\begin{array}{c}\text { Percentage } \\
\text { who replied }\end{array}$ & 22.2 & 11.1 & 7.4 & 0 & 0 & 3.7 \\
\hline Ethnicity & White & Black & Asian & Chinese & Mixed & \\
\hline $\begin{array}{c}\text { Percentage } \\
\text { who replied }\end{array}$ & 70.6 & 5.9 & 2.9 & 2.9 & 5.9 & \\
\hline
\end{tabular}

\subsection{Thames Barrier Park on-site visitor survey}

One hundred and three completed surveys produced a representative sample $(12 \%)$ of the total number of people $(874$, including those that visited more than once over the survey three days) that visited the park over the survey period.

\subsubsection{Where visitors have travelled from}

The results, fig 1 , indicate that $57 \%$ of the visitors came from the local area of Newham and Tower Hamlets (the neighbouring borough) with $43 \%$ being attracted to the park from further afield.

\subsubsection{Areas of the park used by visitors}

The results, fig 2, suggest that most of the major areas of the park were used equally apart from the more specialist areas such as the basket ball court and the children's play fountains.

\subsubsection{Park user activities}

The main activity, fig 3, was taking the children out to play followed closely by relaxing. Exercise or dog walking formed relatively small proportion of the overall activity in the park. 


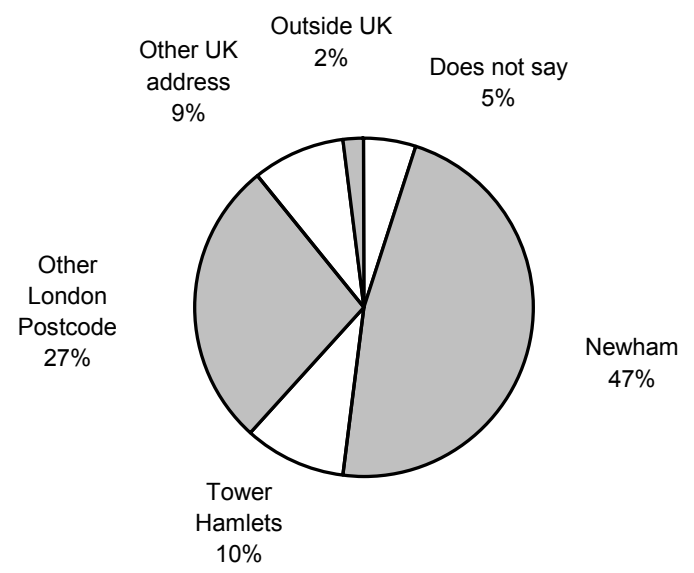

Figure 1: Where visitors have travelled from.

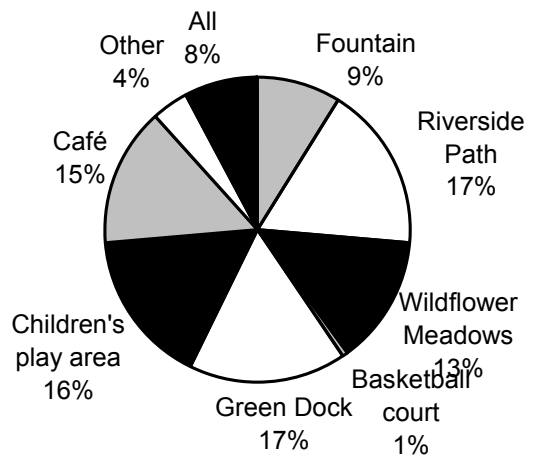

Figure 2: $\quad$ Areas of the park used by visitors.

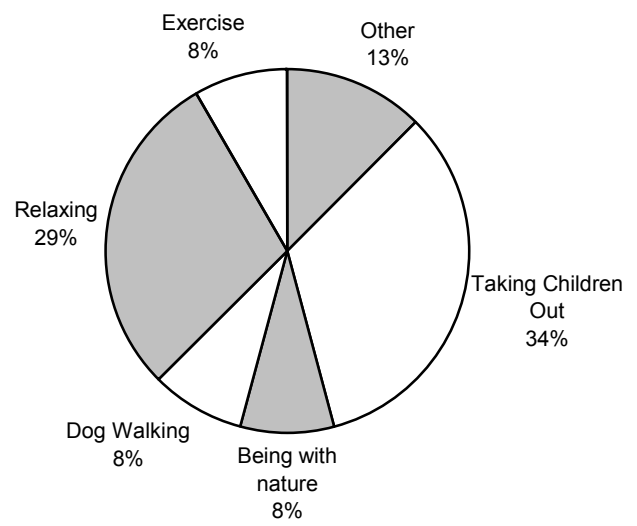

Figure 3: $\quad$ Park user activities. 


\subsubsection{Age and gender}

The gender distribution, fig 4 , favours female (59\%) to male visitors $(42 \%)$. When gender is broken down by age, the majority of users in their $30 \mathrm{~s}$ and $40 \mathrm{~s}$ were females while men made up the majority of people over the age of 60 . Overall, the visitor survey suggests that people using the park are predominantly in their $30 \mathrm{~s}$ and $40 \mathrm{~s}$. Interestingly, there was no recorded use by teenagers.

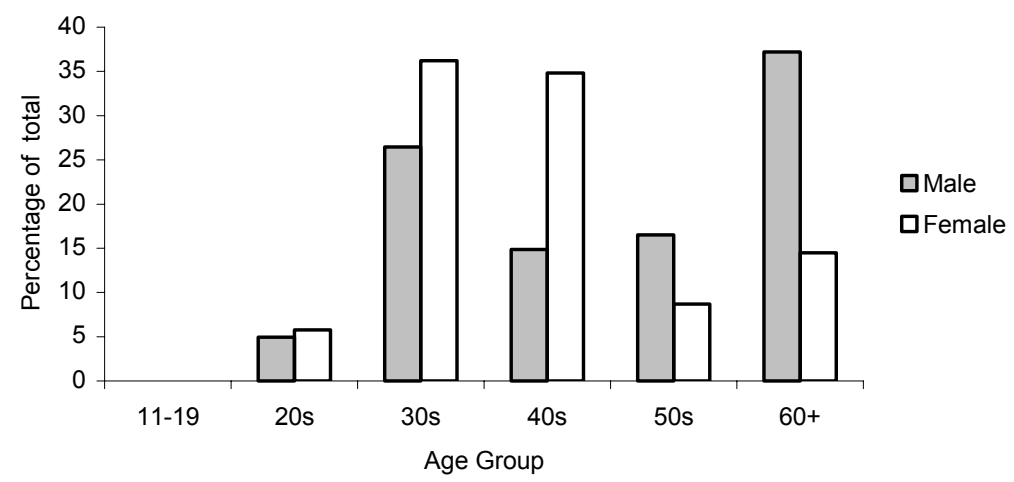

Figure 4: $\quad$ Park user age and gender.

\subsubsection{Park user ethnicity}

The majority of the park users were white, fig 5, with very few minorities using the park. This does not represent the general ethnic community mix in Newham of $40 \%$ white and $20 \%$ black.

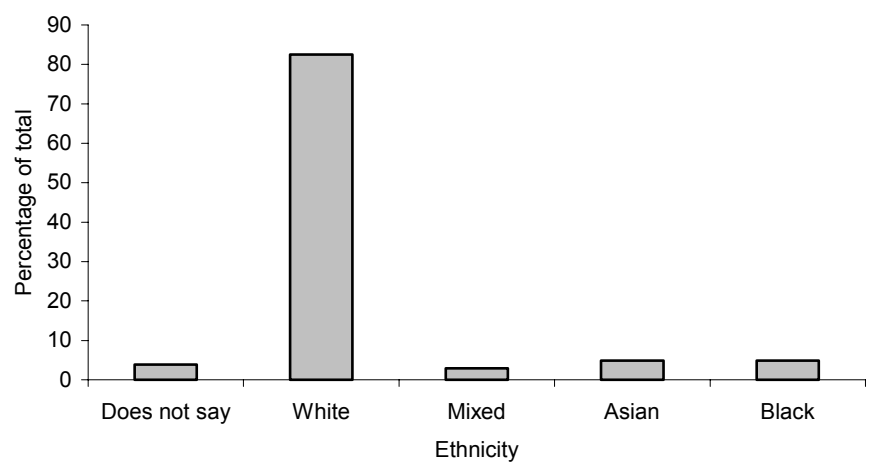

Figure 5: $\quad$ Park user ethnicity.

\subsubsection{Income}

Forty seven percent of respondents left this question unanswered. Of those that did, fig 6 shows that most had an annual income above Newham's average of $£ 27000$ (LBN [2]). 


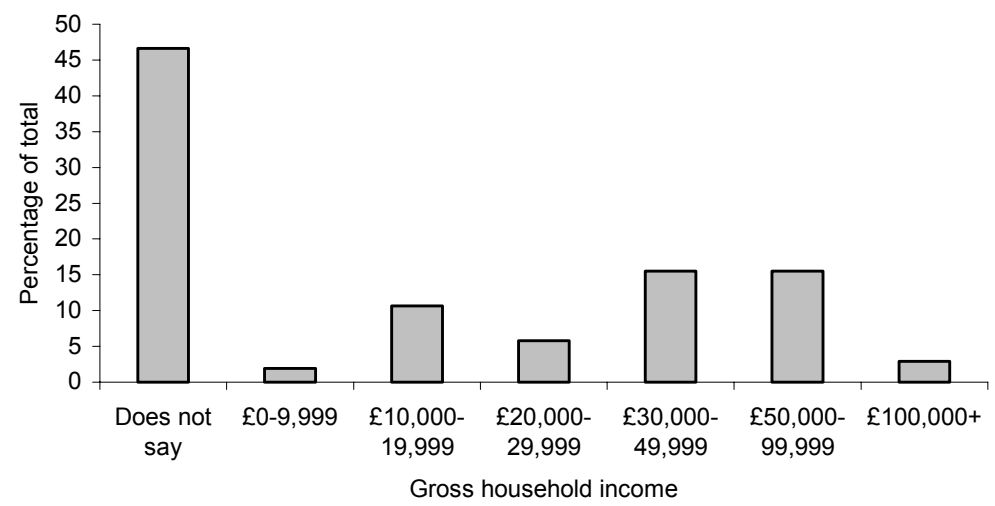

Figure 6: Park user gross household income.

\subsubsection{Transport to the park}

The results show, fig 7, that the vast majority of people travelled to the park by car. Very few came by public transport, on foot or cycled. These findings bear out those on income above.

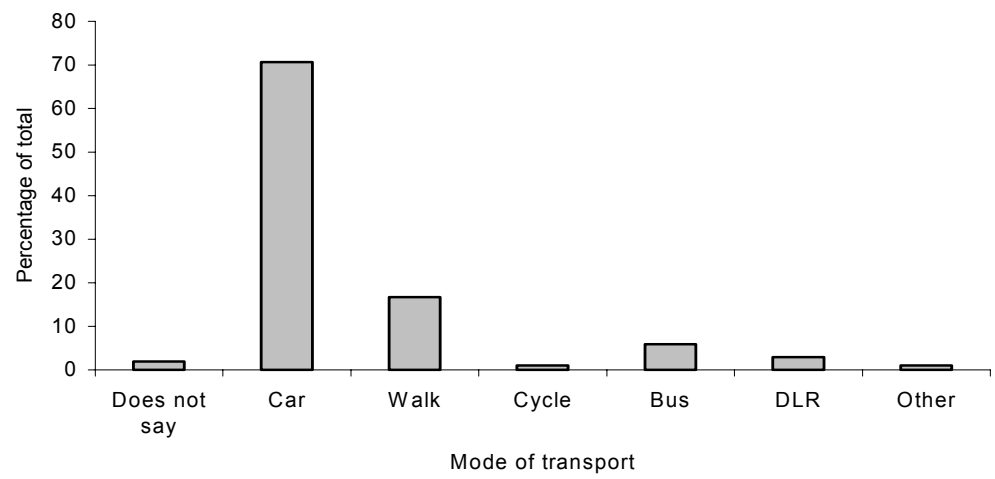

Figure 7: $\quad$ Mode of transport to the park

\subsection{Focus group results}

The focus group agreed that Thames Barrier Park was close to their idea of an 'ideal park', which they defined as being suitable for children, safe, clean and relaxing. Many felt that it was underused and some referred to the park as being 'like my own secret garden'. Although there was a security guard present, people in the early mornings and evenings felt the lack of people made them insecure. They commented that the size of the open spaces and wildflower areas meant that teenage people did not use it to play ball games, which appealed to the older visitors and those with young children. 
There were some negative comments about the park. Those surveyed felt that the imminent removal of the daytime park security guard, would make the park less safe and much more like the local council parks nearby, and threaten future use by a significant group of current users of the park. People were divided on the need for wildflower areas, some seeing them as scruffy and others valuing their ecological value and aesthetic appeal. However, all users thought that they would understand the importance and function of such areas if information boards were erected. This was a comment towards the park with a user consensus that more information should be provided describing the park in terms of the habitats it provides for plant species and communities, wild fauna, historical information about the site, and the history and function of the Thames Barrier.

\section{Discussion and conclusion}

The first objective of the regeneration was that the park was to become a multifunctional space for the local community. Although the results from the community survey were disappointing and the data too weak to form reliable conclusions from, the visitor survey and the focus group results suggest that the park has been successful at meeting this objective. The majority of visitors were from the local community, fig 1, and they appreciated and visited most of the features that the park offers, fig 2, undertaking a wide range of activities fig 3 . However certain age groups, such as teenagers, do not use the park fig 4, possibly because there is insufficient open space to play ball games. In comparison to the other age groups, there were fewer people between the ages of 40 and 50 and yet, at $23.6 \%$, they make up the second largest age group in Newham, (LBN [2]). Results suggest that the mainly female 30-40 age group are accompanying younger children to play in the park, as figure 3 shows that the majority of people use the park to entertain children. The second largest group are visiting for non-physical relaxation with few taking part in exercise. This is almost certainly down to the restricted size of the park and may be a deterrent to other more active age groups or sectors of society.

There are some objectives that the park has been less successful in achieving. The focus group thought that it was a pleasant piece of greenspace which added value to the community in terms of improving the area as a place to live, but the survey results suggest that the park is not reaching out to all members of the community. The ethnic mix of people visiting the park, fig 5, does not reflect the census results (LBN [2]). It wasn't clear from the focus group or community survey why ethnic groups don't visit the park but ethnic exclusion has been highlighted in many studies and reports $[4,5]$. The results also suggest that the park is predominantly attracting higher income groups than is representative of the area, fig 6, according to the census data LBN [2]. This may be because the housing immediately surrounding the park are expensive apartment dwellings and proportionately more people from these apartments are using the park compared to people from areas with lower average income. A second reason may be that the park is separated from other Newham communities by a main road, 
with very large traffic density, and this makes access to the park less easy for people without a car. The census data for Newham shows that almost half the households in Newham, 48.9\% have no vehicular transport at all LBN [2]. Compared to the census data, the park is disproportionately attracting those who own a car, which may be a reflection of those who have the financial means to own one.

Another objective of the park was to develop a destination attraction in its own right and form a significant contribution to the wider tourist development plan for Docklands. Forty-three percent, fig 1, of the visitors to the park came from outside the local area which, given the park's situation and relative newness, should be considered a success.

The park has therefore been successful in creating a formal greenspace on former brownfield land that is used, appreciated and enjoyed by the local community and has had success in attracting some people from outside the local area. It has not been as successful in reaching out to ethnic members of the community or the lower income groups who are possibly excluded by the difficulties in visiting the park without car transport. However, the completion of Pontoon Dock DLR station in December 2005 should greatly enhance access to the site Lewis [6]. Furthermore, the imminent development of Silvertown Quay directly opposite the park, which includes a new aquarium and walkways over the main road should enhance the attraction of the park and its pedestrian access Lewis [6]. Moreover, the 2012 London Olympics to be held in the area, may also draw people to the park. So the future potential for Thames Barrier Park to meet its objectives for the local community and its wider aims to be a destination site is considerable. However, emphasis may be needed to develop programmes and strategies to attract people from ethnic communities and lower incomes.

Results from Thames Barrier have wider reaching implications for future provision of urban greenspace. Many regeneration projects for green space require them to be age inclusive. Our study suggests that this may not be possible in reality nor be desired by important sectors of the community. Most greenspace regeneration projects are designed to maximise access to all ethnic groups. Our study shows that premier greenspace developments in areas with large numbers of people from differing ethnic backgrounds still fail to attract people from non white ethnic backgrounds.

\section{Acknowledgements}

We thank the SUBRIM consortium for financially supporting this work through funding from EPSRC. We also thank Paul Lewis and Phil Riley for the help, advice, information and time that they gave to this project.

\section{References}

[1] Riley, P., Personal communication, September 2004, Marketing and Events Manager, Thames Barrier Park, London, UK. 
[2] London Borough of Newham, (LBN) 2005, census data. http://www.newham.gov.uk/content/democracy/census.jsp

[3] Lewis, P. Personal communication, March 2004, Park Manager, Thames Barrier Park, London, UK.

[4] Morris, N., Black and Minority Ethnic Groups and Public Open Space Literature Review, Edinburgh College of Art and Heriot-Watt University, Edinburgh, UK., 2003. $\quad$ http://www.openspace.eca.ac.uk/pdf BlackMinorityLitRev.pdf

[5] Dunnett, N., Swanwick, C. \& Woolley, H., Improving Urban Parks, Play Areas and Green Spaces, Office of the Deputy Prime Minister, London, UK, 2002. www.odpm.gov.uk/index.asp?id $=1127727$

[6] Lewis, P. Personal Communication, 9 February 2006, Park Manager, Thames Barrier, London, UK. 